\title{
Textual research of 1219 A.D. Guyuan earthquake in Ningxia Hui Autonomous Region, China and discussion on its causa- tive structure*
}

\author{
YUAN Dao-yang ${ }^{1,2),{ }^{*}}$ (袁道阳) LEI Zhong-sheng ${ }^{1,2)}$ (雷中生) ZHANG Jun-ling ${ }^{1,2)}$ (张俊玲) \\ LIU Bai-chi ${ }^{1,2)}$ (刘百箎) LIANG Ming-jian ${ }^{1,2)}$ (梁明剑) \\ 1) Lanzhou Institute of Seismology, China Earthquake Administration, Lanzhou 730000, China \\ 2) Lanzhou Base of Institute of Earthquake Science, China Earthquake Administration, Lanzhou 730000, China
}

\begin{abstract}
On the basis of textual research on the historical earthquake data and the field investigation of 1219 A.D. Guyuan earthquake, we suggest that there is only one strong earthquake occurred in Guyuan area in 1219 A.D., instead of two or three strong earthquakes. We further suggest that the earthquake parameters recorded in the present earthquake catalogs are not definite and should be modified. The occurrence time of this earthquake should be about 11 am, August 7, 1219 A.D. and the heavily-damaged area of this earthquake, the VIII intensity area, should be located among the regions of Guyuan, Pingliang and Longde county cities. The epicenter area should be near Guyuan city. The magnitude of this earthquake is about 7 and it has intensity about larger than or equal to IX within the epicenter area. The major axis direction of the heavily-damaged area strikes in north-northwest that is approximately consistent with the strike of the Liupan Shan thrust fault zone. The new tectonic activity of the Liupan Shan thrust fault zone resulted in the $M 7$ Guyuan earthquake in 1219 A.D.
\end{abstract}

Key words: 1219 A.D. Guyuan earthquake; textual research of historical earthquake; causative structure; eastern Liupan Shan piedmont fault

CLC number: P315.5 Document code: A

\section{Introduction}

In 1219 A.D. (the third year of Xingding of Emperor Xuan in Jin Dynasty), a strong earthquake occurred in Guyuan and adjacent area, which is located in the south of Ningxia Hui Autonomous Region. From the historical records, we know that "the earth was trembled intensely, and the damages around Pingliang, Zhenrong and Deshun states were especially serious as farmhouses were collapsed, tens of thousand people and double various domestic animals were dead during the earthquake" (XIE and CAI, 1983; Lanzhou Institute of Seismology, State Seismological

\footnotetext{
* Received 2008-04-22; accepted in revised form 2008-08-13.

Foundation item: Appropriative items of Institute of Earthquake Science, China Earthquake Administration (2008692, 2008690); National Natural Science Foundation of China (40372086).

Contribution No. LC2008013, Lanzhou Institute of Seismology, China Earthquake Administration.

^Author for correspondence: yuandaoyang@163.com.
} 
Bureau, 1985). But there is still no agreement on the occurrence time of this earthquake because of long historical time and sparse historical data. This has been presented in different earthquake catalog versions as follows (Table 1): April Guiwei (A day calculated by ancient Chinese calendar, below is the same) (i.e., April 18), June Xinsi (i.e., June 18) and June Wuzi (i.e., June 25) (GU, 1983; Lanzhou Institute of Seismology, State Seismological Bureau, 1985; Department of Earthquake Disaster Prevention, State Seismological Bureau, 1995; Earthquake Administration of Ningxia Hui Autonomous Region, 1982, 1988). Therefore, how many strong earthquakes occurred in the area adjacent Guyuan in 1219 A.D.? Is there one earthquake or several earthquakes? Or the discrepancy was due to the wrong records of origin time. Furthermore, is the magnitude suitable? What is the causative structure of this earthquake? All these above problems indicate that there is still no consistency or accurate recognition about the 1219 A.D. Guyuan earthquake. By this present study, we provide a new idea related to the earthquake parameters and seismogenic structure in the integration with some new information about 1219 A.D. Guyuan earthquake. All of these are based on the textual research of earthquake historical records, the field survey and the research findings of active tectonics around this region. The result is valuable for analyzing the seismic activity in Liupan Shan region, and the north segment of South-North seismic belt where much more attention have been paid to the seismic risk in recent years.

Table 1 Parameters of Guyuan earthquake in 1219 A.D.

\begin{tabular}{|c|c|c|c|c|c|}
\hline Origin time of earthquake & $\begin{array}{l}\text { Epicentral location } \\
\text { (coordinate) }\end{array}$ & $\begin{array}{l}\text { Epicentral } \\
\text { accuracy }\end{array}$ & Magnitude & $\begin{array}{l}\text { Epicentral } \\
\text { intensity }\end{array}$ & Earthquake catalogue \\
\hline $\begin{array}{l}\text { June 2, } 1219 \text { A.D.(i.e., April 18, } \\
\text { the third year of Xingding in Jin } \\
\text { Dynasty) (Julian calendar) }\end{array}$ & $\begin{array}{c}\text { Guyuan } \\
\left(36.0^{\circ} \mathrm{N}, 106.2^{\circ} \mathrm{E}\right)\end{array}$ & & $6 \frac{1}{2}$ & VIII IX & $\begin{array}{l}\text { Earthquakes catalogue in China (GU, } \\
\text { 1983) }\end{array}$ \\
\hline $\begin{array}{l}\text { June 9, } 1219 \text { A.D.(i.e., April } \\
\text { Guiwei (18), the third year of } \\
\text { Xingding of Emperor Xuan in } \\
\text { Jin Dynasty) }\end{array}$ & $\begin{array}{l}\text { South of Guyuan } \\
\left(35.6^{\circ} \mathrm{N}, 106.1^{\circ} \mathrm{E}\right)\end{array}$ & & $6^{1 / 2}$ & VIII $\sim$ IX & $\begin{array}{l}\text { Catalogue of strong earthquakes in } \\
\text { Shaanxi, Gansu, Qinghai provinces and } \\
\text { Ningxia Hui Autonomous Region (Lan- } \\
\text { zhou Institute of Seismology, State } \\
\text { Seismological Bureau, 1985) }\end{array}$ \\
\hline $\begin{array}{l}\text { June 9, } 1219 \text { A.D.(i.e., April 18, } \\
\text { the third year of Xingding of } \\
\text { Emperor Xuan in Jin Dynasty) }\end{array}$ & $\begin{array}{l}\text { South of Guyuan } \\
\left(35.6^{\circ} \mathrm{N}, 106.1^{\circ} \mathrm{E}\right)\end{array}$ & 4 & $6 \frac{1}{2}$ & VIII $\sim \mathrm{IX}$ & $\begin{array}{l}\text { Historical strong earthquakes catalogue } \\
\text { in China (Department of Earthquake } \\
\text { Disaster Prevention, State Seismological } \\
\text { Bureau, 1995) }\end{array}$ \\
\hline $\begin{array}{l}\text { June 9, } 1219 \text { A.D.(i.e., April 18, } \\
\text { the third year of Xingding of } \\
\text { Emperor Xuan in Jin Dynasty) }\end{array}$ & $\begin{array}{l}\text { South of Guyuan } \\
\left(36.0^{\circ} \mathrm{N}, 106.2^{\circ} \mathrm{E}\right)\end{array}$ & & $6 \frac{1}{2}$ & VIII IX & $\begin{array}{l}\text { Earthquakes catalogue in Ningxia region } \\
\text { (Earthquake Administration of Ningxia } \\
\text { Hui Autonomous Region, 1982) }\end{array}$ \\
\hline $\begin{array}{l}\text { July } 30,1219 \text { A.D.(June } \\
\text { Guiwei) }\end{array}$ & $\begin{array}{l}\text { Pingliang, } \\
\text { Zhenrong and } \\
\text { Deshun }\end{array}$ & & $6 \frac{1}{2}$ & VIII $\sim$ IX & $\begin{array}{l}\text { Collection of earthquake data of Ningxia } \\
\text { region (Earthquake Administration of } \\
\text { Ningxia Hui Autonomous Region, 1988) }\end{array}$ \\
\hline
\end{tabular}

\section{Main historical data and problems about 1219 A.D. Guyuan earthquake}

\subsection{Main historical data}

The main historical data about 1219 A.D. Guyuan earthquake are as follows (XIE et al, 1983; Lanzhou Institute of Seismology, State Seismological Bureau, 1985; Earthquake Administration of Ningxia Hui Autonomous Region, 1988).

1) History of Jin Dynasty • Civilian Records reported "On April Guiwei (18), the third year of Xingding of Emperor Xuan in Jin Dynasty, a windy storm suddenly appeared in Shaanxi Province 
with its sound like thundering, and the earth trembled intensely. On July Gengzi (7), the Emperor remitted taxes of Shaanxi Province for the earthquake damages, and then ordered his adherent SHAN Si-zhong hold a memorial ceremony in Shangqing palace for the earthquake at Dingsi (24)". "A windy storm suddenly appeared in Shaanxi Province with its sound like thundering, and the earth trembled intensely. The damages in Pingliang, Zhenrong and Deshun states were especially serious, farmhouses collapsed, tens of thousand people and double various domestic animals died during the earthquake".

2) History of Jin Dynasty • Annals of Emperor Xuan (Vol.15) reported "On June Wuzi (25), an earthquake occurred around Pingliang area. The Emperor transmitted a rescript and recommended a government official GUO Zhu to appease the army soldiers and local people. On October Yichou (2), the Pingliang prefecture held a fete ceremony for the earthquake. When the ceremony just began, auspicious clouds appeared suddenly, impetrated God bless".

3) History of Jin Dynasty • Biography of Bahulu (Vol.108) wrote "In June, the third year of Xingding, an earthquake occurred around Pingliang area. HU Lu sent a letter and advised to the Emperor, "the God does not speak, but tells people by some evidences; therefore the occurrence of disaster must have some reasons. Please tell the officials, all the departments of the government, do well otherwise they will be punished by the God". The emperor was glad to accept the suggestions and sent a government official GUO Zhu to investigate the situation of damages and appease the army soldiers and local people".

4) History of Jin Dynasty • Biography of loyalism (Vol.124) recorded "SHANG Heng inaugurated the governor of Weirong county (now the Weirong town of Jingning county). It was a famine year at the third year of Xingding. The citizens couldn't afford food at any places in the city. When SHANG Heng knew these situations and inspected, he ordered to open the storehouses and help the citizens, therefore, most of them could be alive. Later, the county city wall was collapsed during an earthquake. At that time, the Western Xia regime invaded the Weirong county city by using the opportunity of earthquake, SHANG Heng ordered the soldiers and local tyrants defended and then kept the city safe".

According to the above historical data records, the present earthquake catalogs confirm the epicenter of this earthquake in southern Guyuan area, and the magnitude is about $61 / 2$ and the epicentral intensity is about VIII IX (Table 1). But the records of the original time of the earthquake are in disagreement. The records are at April Guiwei (18) or June Wuzi (25) etc., the third year of Xingding of Emperor Xuan in Jin Dynasty.

\subsection{New historical data and the proposed problems}

On June 9, 1979 A.D., when several middle school students were playing in the western side of southern gate of the city wall in Guyuan county (the Yuanzhou district of Guyuan city at present), Ningxia Hui Autonomous Region, they found a quadrel which chiseled posy on the surface, and kept in the destroyed inner city wall surface. The brick is in square shape, with length about $38 \mathrm{~cm}$ and $6 \mathrm{~cm}$ thick, $11 \mathrm{~kg}$ weight. The posy chiseled on September 1, the second year of Jingtai in Ming Dynasty (e.g., 1451 A.D.), and reshipped a paragraph of words which recorded on the brick surface in Jin Dynasty about the reconstruction of Zhenrong city walls "...... By supervising and summoning more than 5000 officials, soldiers, craftsmen, civilians et al, the collapsed city walls was rebuilt on July 22, the second year of Jingtai in Ming Dynasty, and one quadrel was dug out. On the quadrel surface it was carved as following words that the earth trembled at the time $\mathrm{Si}$ (about 11 o'clock in the morning), June 18, the third year of Xingding in Jin Dynasty, and the houses and temples of Zhenrong city were collapsed. More than 20000 soldiers, civilians were 
dispatched to rebuild the collapsed houses and temples on April 21, the forth year of Xingding, and the construction was finished until May 15".

After the brick chisel was found, there are three different views about the origin time of this earthquake, besides the April Guiwei (18) and June Wuzi (25) mentioned above, and another record of the time $\mathrm{Si}$ (about $11 \mathrm{am}$ ), June 18.

The first view is that there were two earthquakes. One earthquake occurred on April Guiwei (18), and another one occurred on June 18 (Xinsi) ${ }^{\oplus}$.

The second view is that there is only one earthquake occurred on June 18. It is very clear recorded in the quadrel posy unearthed in Guyuan city. The origin time of April Guiwei (18) should be one wrong record of June 18. The date recorded in History of Jin Dynasty • Annals of Emperor Xuan as "On June Wuzi (25), Pingling state etc., occurred an earthquake", should be the date of promulgating the rescript and comforting the civilians, not the earthquake occurred date $\left.{ }^{\circledR(}\right)$.

The third view is that June Wuzi (25) is another earthquake occurrence time, besides the above two earthquakes. So, there are totally three earthquakes (Earthquake Administration of Ningxia Hui Autonomous Region, 1988).

For the above different views of 1219 A.D. Guyuan earthquake, there is not a uniform recognition among the Chinese historical earthquake researchers. So, the earthquake parameters are in disagreement among those various published earthquake catalogs (Table 1). Only the book, Collection of Earthquake Data of Ningxia region, edited by Earthquake Administration of Ningxia Hui Autonomous Region (1988) wrote that "The date of April Guiwei (18) should be the wrong record of June 18 ". So, by the simple earthquake catalogs provided by this book, it is confirmed that the occurrence time of this earthquake was at June Guiwei (July 30). It is a pity that the editor has made a mistake during date conversion, for April Guiwei is 18, June Guiwei is 20, but June Xinsi should be June 18.

\section{Comprehensive analysis of the occurrence time of the 1219 A.D. Guyuan earthquake}

According to the comprehensive analysis of the historical data, we think that there is only one strong earthquake occurred in the adjacent area of Guyuan, and the origin time of this earthquake is at the time Si of Jimao (June 18), which is about 11 am in the morning, August 7, 1219 A.D. (July 31 according to Julian calendar). The date of April Guiwei (18) should be the wrong recorded date of June 18. The reasons are shown below:

1) The new discovery of brick epigraph carved in the eleventh year of Jiajing in Ming Dynasty confirmed the epigraph carved in the second year of Jingtai in Ming Dynasty.

In August, 1996, the Guyuan County Museum collected a piece of earthquake brick epigraph from GAO Chu-xin, the principal of Luban temple in the eastern mountain of Guyuan county, which was unearthed in the site of the temple in 1994. This brick epigraph was carved in the eleventh year of Jiajing in Ming Dynasty (1532 A.D.), and the brick is rectangle shape (length about $32.5 \mathrm{~cm}$, width about $25.5 \mathrm{~cm}$ ), and was constituted of yellow sand. The posy said "At Jimao, i.e.,

\footnotetext{
(1) XU Cheng and HAN Zhao-min. 1987. Excavated brick chisel of Ming Dynasty in Ningxia. Edited by the office of chorography in Guyuan region. The historical data of Guyuan region (the second volume), 58-59 (in Chinese).

(2) ZHANG Si-yuan. 1987. About the 8 middle-strong earthquakes since 13 Century in Guyuan region. Edited by the office of chorography in Guyuan region. The historical data of Guyuan region (the second volume), 154-155 (in Chinese).

(3) LUO Feng. 1982. How many earthquakes occurred in Shaanxi region in the third year of Xingding in Jin Dynasty. Edited by the office of chorography in Guyuan region. The historical data of Guyuan region (the second volume), 162-164 (in Chinese).
} 
June 18, the third year of Xingding in Jin Dynasty, the earth trembled at the time Si, from northwest to southeast. The Zhenrong state city wall baileys, houses and temples were all nearly collapsed, and all the people were scattered. On April 21, the forth year of Xingding, the Emperor dispatched the soldiers, civilians more than 20000 to rebuild the collapsed walls, houses and temples, and the construction was finished until May 15". The contents of the new discovery brick posy are nearly the same with the brick epigraph carved in the second year of Jingtai in Ming Dynasty which was unearthed in the city wall of Guyuan county city. They are in great agreement with each other, and further attested the reliability of the historical data of the two brick epigraphs. At present, both of the two brick epigraphs are kept in the Museum of Guyuan city.

2) History of Jin Dynasty recorded might be wrong

Besides the books as History of Jin Dynasty • Civilian Records and History of Jin Dynasty • Annals of Emperor Xuan which claimed the earthquake occurred at Guiwei (18) of April, the third year of Xingding of Emperor Xuan in Jin Dynasty, the author of those books, TUO Tuo, also compiled the history of Song and Liao two Dynasties as a main editor. At the seventh year of Zhizheng of Emperor Shun in Yuan Dynasty (1347 A.D.), TUO Tuo was the premier of Yuan Dynasty. Tuotuo's writing style is more precise. The History of Jin Dynasty as one of the 24 history records in Chinese history has its authority. But since the occurrence of the 1219 A.D. earthquake, it has been more than 100 years when TUO Tuo edited the History of Jin Dynasty, so it is reasonable that some mistakes might have been made about the detailed time.

3) The brick epigraph indicates only one earthquake

The unearthed brick epigraph of Jin Dynasty was carved at the second year of the earthquake occurrence. Although the brick epigraph of Jin Dynasty had lost, the two brick epigraphs of Jingtai and Jiajing in Ming Dynasty had rerecorded the contents of the brick epigraph of Jin Dynasty, so the historical data are much more reliable and authoritative. If there was one earthquake in April, the third year of Xingding in Jin Dynasty, the brick epigraph would be able to mention it.

4) The coincidence of dates

The date records of the occurrence time of the earthquake in April and June both are showing on 18, and during daytime. Further more, the historical data which recorded the earthquake on June 18 had provided the detailed time, so it is more reliable. We prefer to believe the later.

5) Clue from the submitted Bahulu letter

After the earthquake occurred at Pingliang area etc., BA Hu-lu, a government official and the command envoy of the army in Shaanxi Province, sent a letter to the Emperor for reporting the earthquake (History of Jin Dynasty • Biography of Bahulu, Vol.108) "the God does not speak, but tells people by some evidences, the occurrence of disaster must have some reasons. Please tell the officials and all the departments of the government do well, otherwise they will be punished by the God". The emperor accepted his suggestion and "sent a government official GUO Zhu to investigate the situation of damages and appease the army soldiers and local people". If there were two destroyed strong earthquakes occurred continuously in two months, the letter submitted to the emperor by BA Hu-lu would be able to mention it.

6) The records coincidence with the Records of Guyuan State and the two brick epigraphs

The Records of Guyuan State edited in the eleventh year of Jiajing (1532 A.D.) recorded "At June 18, the third year of Xingding of Emperor Xuan in Jin Dynasty, the city walls were collapsed due to the earthquake, and then about 20000 people were sent out to rebuild since April 21 and all the construction was finished, the forth year of Xingding. There is a stone monument kept in the Town God temple, and the present Guyuan state city wall is its former rampart". The Records of 
Guyuan State did not mention an earthquake in April, but June 18 only. We therefore conclude that the date of the earthquake in April was a wrong record by History of Jin Dynasty.

7) All the rescue activities by the Jin Dynasty government were after June 18

Although the History of Jin Dynasty $•$ Civilian Records recorded that the earthquake occurred on April Guiwei, there were not any records about the rescue activity. The seventh day, June Wuzi (25), after the earthquake occurred in June recorded by the History of Jin Dynasty, the Jin Dynasty government sent an official GUO Zhu "to appease the army soldiers and local people". At July 7, the Emperor transmitted a rescript and remitted the Shaanxi province taxes, then sent his adherent SHAN Si-zhong to Shangqing palace hold a memorial ceremony for the earthquake on July 24. All the rescue activities were after June 18. If the earthquake occurred at April Guiwei, generally the rescue activities should begin during April or May, not till to late of June 18.

\section{Epicentral location of the earthquake}

As for the historical earthquake, it is usually thought that the most serious damaged area is regarded as the epicenter area of the earthquake. The records of damaged area during the earthquake in 1219 A.D indicate that it is around the Zhenrong state and Weirong county etc. "The city walls, houses and temples were nearly destroyed by the earthquake in Zhenrong city, and all the people were scattered"; "The city walls were collapsed because of the earthquake in Weirong town". Additionally, the History of Jin Dynasty recorded "The damages in Pingliang, Zhenrong and Deshun states were especially serious during this earthquake". Therefore, the textural research of these above areas is the key to identify the location of epicenter of the earthquake.

\subsection{Location of the Zhenrong state city of Jin Dynasty}

For the location of Zhenrong state city of Jin Dynasty, there are some different views in the historiography field. Some experts think that it should be at present-day Guyuan city area, but others think it should be in Kaichengliang town. But we think that it should be more reasonable to identify the location in Guyuan city area, because the earthquake brick epigraph was excavated in the county city wall.

\subsection{Textural research of the location of Deshun state city in Jin Dynasty}

The historical data recorded that Deshun prefecture was established on the bases of Longgan town at the third year of Qingli in Jin Dynasty (1043 A.D.). Deshun in Chinese means that "to obey the rule of Emperor for the benevolent policy". At the second year of Huangtong in Jin Dynasty (1142 A.D.), Deshun prefecture was renamed as Deshun state. The location of Deshun state remains one large contentious question in the historiography field. Such as the Annals of Jingning County (Compiling Committee of Annals of Jingning County, 1993) and the Annals of Longde County (Compiling Committee of Annals of Longde County, 1998) both indicated the Deshun state city was in either of their own county city. But the previously published earthquake catalogs all showed that the Deshun state city was at present county of Jingning (XIE et al, 1983; Lanzhou Institute of Seismology, State Seismological Bureau, 1985; GU et al, 1983; Department of Earthquake Disaster Prevention, State Seismological Bureau, 1995; Earthquake Administration of Ningxia Hui Autonomous Region, 1988). By the textual research of corrected historical data and the field investigation, we think that the capital city of Deshun state should be in the present Longde county city. The main evidences are shown as follows.

1) Historical Geography Maps in China, Vol. 6 (TAN, 1982) indicates the Deshun state of Jin Dynasty in the present Longde county city. 
2) The epigraph records in Guangji Buddhist temple. Guangji Buddhist temple was located at southern corner of the inner city wall, Longde county city in Ming Dynasty, now at the second lane of the Linquan new village, outside of southern gate of Longde county city. One stele was unearthed at this site in 1980, named as "the merits and virtues records installed in Guangji Buddhist Temple”, which was built on April 8, the twelfth year of Dading in Jin Dynasty (1172 A.D.). On the facade of the stele, the pagodas, palaces, and monk houses etc. in Guangji Buddhist temple were recorded. When the pagoda was buried, "people must be fasted seven days and nights, an impressive and dignified ceremony was held for the merits and virtues pagoda with fancy candles" (Compiling Committee of Annals of Longde County, 1998). There was a large quantity of officials in Deshun state to attend the buried ceremony and contribute gifts, such as WANG Sheng-xian, the governor of Deshun state; ZHANG Cong, the district attorney of Deshun state; JIANG De-ming, the military general of Deshun state; HAO Ren, the military judge of Deshun state, and other state officials, military officers in Deshun state and the eleventh military general of the Xiqin Province, PU Cha, et al. All these indicated that the site of Deshun state in Song and Jin Dynasties is in the present Longde county (Compiling Committee of Annals of Longde County, 1998).

3) Lots of tombs and temples of Jin Dynasty are distributed in the area adjacent to Longde county city. A tomb of Jin Dynasty was found in November, 1986, when the commerce building of Longde county was built. Coins of Northern Song Dynasty, several "Zhenglong silver/gold ingots", copper mirror, millstone and copper tribunal seal etc. were excavated from the tomb. Besides the Guangji Buddhist temple, there are Huize king ancestral temple, Hanwei ancestral temple (HAN Qi, a general in Song Dynasty, he was titled Wei Duke after his death), grotto temple, Puzhao temple, Zishi yard of Jingan temple, etc. In 1984, a paragraph words, written on rice paper, "the third of imperial examination WU Zong-da", "the forth year of Dading (1164 A.D.)" etc., was found on the wall when the yellow grass mud skin was flaked off, in the small grotto, "Xuansheng palace", right side of the middle palace of the grotto temple. Only 3 tombs of Song and Han Dynasties were found in Jingning county region, and no cultural relic of Jin Dynasty was unearthed.

4) The description by the Dictionary of Gansu Province. The Dictionary of Gansu Province (Compiling Committee of Dictionary of Gansu Province, 2000) described under the entry of "Deshun state": "the Deshun state was built on the base of Longgan town which was governed by Wei state in the third year of Qingli of Emperor Ren in Song Dynasty, and the governance of the state was located at present Longgan town in Longgan plain, now in the region of Longde county, Ningxia Hui Autonomous Region".

5) There is a remnant at Longde county city. There is a remnant of Deshun state city at the southern bank of Tianshui river in Liupan Shan, $10 \mathrm{~km}$ east of Longde county city. It shows that the ancient city site was a rectangle shape, with its length of south-north direction about $900 \mathrm{~m}$, and width of west-east direction about $800 \mathrm{~m}$. The wall was rammed by loess, and collapsed seriously. The relative well-preserved city wall was measured, with about $12 \mathrm{~m}$ high and base width $12.5 \mathrm{~m}$, top width $6 \mathrm{~m}$. At present, the sunk fence is $1.3 \mathrm{~m}$ high, $0.4 \mathrm{~m}$ thick and remains as only 3 segments, $1370 \mathrm{~m}$ length in total. Deshun has been a state since Yuan Dynasty, and transferred Longde county city from Huojia town to there (Compiling Committee of Annals of Longde County, 1998).

6) The origin of the title "Jingning". The name of "Jingning" was appeared since Yuan Dynasty. Yuan Dynasty established Jingning state, which followed the first word of "Jingbian village" in Song and Jin Dynasties, and based upon its meaning as being quiet and peaceful. The Dictionary of Gansu Province (Compiling Committee of Dictionary of Gansu Province, 2000) 
described under the entry of "Jingbian village": "At the second year of Tianxi in Song Dynasty (1018 A.D.), general ZHOU Wen-zhi led and built the southern town, the emperor obliged the town name Jingbian village when the town was finished, therefore, it is now the Jingning county city, once Jingning state in Yuan Dynasty". So Jingning should not be the Deshun state when earthquake occurred in Jin Dynasty.

\subsection{Location of Pingliang state}

Pingliang city has a long history. It was built as the Pingliang town at northwestern side of present Pingliang city and the Pingliang County was established in Pre-Qin Dynasty. Weizhou county was set up in the fourth year of Yuanhe of Emperor Xian in Tang Dynasty, and became Pingliang state in the seventh year of Zhenghe (1117 A.D.) which governed five states and three prefectures in total including Weizhou, Deshun and Zhenrong states etc. At the twenty-seventh year of Dading in Jin Dynasty (1187 A.D.), the government of Jin Dynasty promoted Weizhou county to Pingliang state, and governed five counties or bases including the Pingliang, Panyuan (now at the northern bank of Jing river in the forty post) etc. In 1209 A.D., before the earthquake occurred, a marshal mansion was set up in Pingliang state in order to defend the aggression by Mongolia and Western Xia regime.

\subsection{Identification of the 1219 A.D. earthquake epicenter}

On the basis of textual research on the historical data and the involved towns during the earthquake in 1219 A.D., we definitely think that the most seriously damaged towns are Zhenrong (now Guyuan city), Deshun (now Longde county city) and Pingliang, meanwhile the city wall was collapsed at Weirong town (now Weirong town of Jingning county) during the earthquake. So the damaged area of this earthquake should include the above 4 towns. The unearthed brick epigraphs only recorded the detailed destroyed situations in Zhenrong state. For the Deshun and Pingliang two states, only the especially serious damages were mentioned, but no detail calamities were recorded. So the epicenter area should be among the three towns but much more adjacent to the Zhenrong town (now Guyuan city), the epicentral location is in the southeastern area of Guyuan city with a coordinate of $35.9^{\circ} \mathrm{N}, 106.3^{\circ} \mathrm{E}$, with a precision degree of III. The error should be less than or equal to $50 \mathrm{~km}$ (Figure 1). The new location is much more to the north than the former location.

\section{Identification of the magnitude and intensity}

\subsection{Identification of intensity of each site}

The assessment of intensity is mainly according to the Intensity Table of Earthquake in China (GB/T17742-1999) (China State Bureau of Quality and Technical Supervision, 1999) and the Simple Table of Intensity and Magnitude of Historical Earthquake (Department of Earthquake Disaster Prevention, State Seismological Bureau, 1995) etc.

1) The assessment of intensity in Zhenrong state

The historical data recorded the earthquake damages in Zhenrong state (now the Guyuan city) are mainly the brick epigraph in Jin Dynasty and the History of Jin Dynasty. The damages include: (1) the city walls were nearly all collapsed, and rebuilt in the next year; (2) Houses and temples were nearly all collapsed; (3) lots of people and domestic animals died. Obviously, the earthquake damages are most serious in Zhenrong state. The intensity of Zhenrong should be assessed more than IX.

2) The assessment of intensity in Pingliang and Deshun towns

According to the History of Jin Dynasty records, "the damages in Pingliang, Zhenrong and 
Deshun states were especially serious, such as farmhouses were collapsed; tens of thousand people and double various domestic animals were dead during the earthquake in 1219 A.D.". Because the historical data records are in general not detail, and Pingliang, Deshun (now Longde county city) two states have no more detailed historical data records, so we conclude the damages in the two towns are a little lighter than the Zhenrong state. The intensities of Pingliang and Deshun should be assessed about VIII.

3) The assessment of intensity in Weirong town

Only one historical data, "the city walls were collapsed during the earthquake", reported the damage of Weirong town (now the Weirong town in Jingning county), and no other damages were recorded. According to "the city walls were collapsed for earthquake", the intensity in Weirong town should be assessed about VII.

According to the assessment results of all the destroyed sites mentioned above, we can draw the isoseismal line of 1219 A.D. Guyuan earthquake in Ningxia region (Figure 1). It looks like an asymmetry fat ellipse. The major axis orientation is in north-northwest direction. The major axis diameters are about $30 \mathrm{~km}$ length in the $\geq \mathrm{IX}$ intensity area, about $100 \mathrm{~km}$ length of VIII intensity area. Along the minor axis direction, the intensity declined eastward very fast, at these places of Pengyang town (now Pengyang county city) and Yuanzhou town (now Zhenyuan county city), short distance to the epicenteral area, there were no damages recorded, we suppose that the destroy was small. On the contrary, the intensity declined westward much more slowly, the Weirong town, about $70 \mathrm{~km}$ far from the epicenteral area, experienced the damage of intensity about VII.

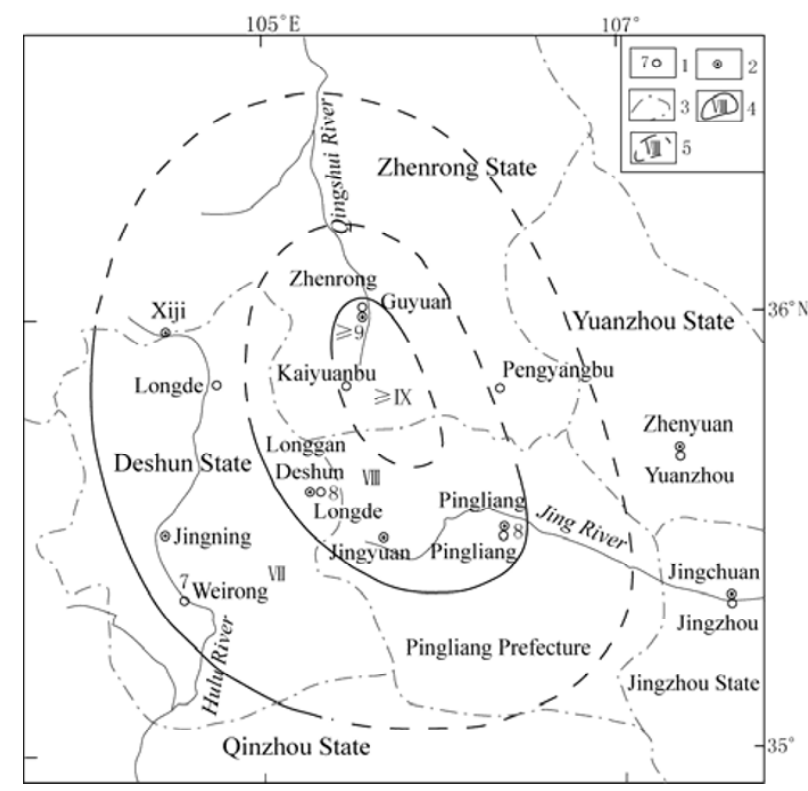

Figure 1 The isoseismal line of Guyuan earthquake in Ningxia in 1219 A.D.

1. Geographical name in the Jin Dynasty (The number represents the intensity of earthquake); 2. Present geographical name; 3 . The boundary of state; 4 . Isoseismal line of earthquake; 5 .The speculated isoseismal line

\subsection{Assessment the magnitude}

On the basis of the statistical relationship between the magnitude and the intensity in the western region of Chinese mainland (Department of Earthquake Disaster Prevention, State Seismological Bureau, 1995), $M=0.605 I_{0}+1.376$, suppose the epicentral intensity more than IX, 
$M \geq 6.8$ can be calculated.

According to the damage assessment results, the major axis is about $100 \mathrm{~km}$ of the intensity VIII isoseismal line of Guyuan earthquake. If we consider the intensity VIII isoseismal line area as the fault length to generate this earthquake, using the statistical relationship between the magnitude $(M)$ and the causative fault length $(L)$ in Chinese mainland established by GUO and QIN (1973), $M=2.1 \log L+3.3, M=7.5$ is obtained from the calculation.

Considering the results of calculation by the statistical relationship, we comprehensively assess the magnitude of the earthquake in 1219 A.D. is about 7.

\section{Discussion on causative structure of 1219 A.D. Guyuan earthquake}

On the basis of the textual research on the historical data, the major axis of the heavily-damaged area (VIII intensity area) of the 1219 A.D. Guyuan earthquake isoseismal line was almost consistent with the strike of the late Quaternary active tectonics in Liupan Shan area, south of Ningxia Hui Autonomous Region. Liupan Shan located at the transitional area between the eastern termination of Haiyuan active fault zone, a large left-lateral strike-slip fault, and the Guguan-Gongxian-Baoji fault zone, in the northern side of eastern margin of the Tibetan Plateau (Figure 2, $F_{1}, F_{2}$ ). According to the active tectonics investigation results, there has been developed a group of arcuate thrust-fold zones with a strike of north-northwest, dip southwest and inclination northeast (Institute of Geology, State Seismological Bureau and Ningxia Hui Autonomous Region Seismological Bureau, 1990; Zhang et al, 1991; SUN and DENG, 1994; XIANG et al, 1998, 1999). The active tectonics in Liupan Shan area mainly include the main strike-slip fault of Haiyuan $\left(F_{1}\right)$, Xiaokou fault $\left(F_{2}\right)$, Madong Shan fold zone $\left(F_{3}\right)$, the eastern Liupan Shan piedmont fault $\left(F_{4}\right)$, Xiaoguan Shan fault $\left(F_{5}\right)$ and the Guguan-Gongxian fault $\left(F_{6}\right)$ etc (Figure 2 ). The heavily-damaged area of 1219 A.D. Guyuan earthquake is mainly related to the eastern Liupan Shan piedmont fault and Xiaoguan Shan fault which constitute the main body of Liupan Shan reverse nappe tectonic zone.

According to the latest tectonic activity investigation and paleoearthquake research along the eastern Liupan Shan piedmont fault, it is a general $\mathrm{N} 20^{\circ} \mathrm{W}$ striking arcuate thrust-fold zone, and consists of three secondary fault strands in a right-stepping en echelon arrangement, with $87 \mathrm{~km}$ in length. The northern segment of the eastern Liupan Shan piedmont fault is characterized by left-lateral strike-slip, and developed a series of left-laterally offset geomorphic features, such as ridges, stream valleys, and by concave topography and fault scarps along the fault. The average horizontal slip rate of the fault is about $1 \sim 3 \mathrm{~mm} / \mathrm{yr}$, and vertical slip rate is $0.9 \mathrm{~mm} / \mathrm{yr}$ (XIANG et $a l, 1998)$. There were strong earthquakes with magnitude about 6 occurred along this fault. The middle and southern segments of the eastern Liupan Shan piedmont fault are characterized by thrust features and developed a series of duplicate anticline on the hanging wall (southwestern wall) which are dipping to the southwest (Zhang et al, 1991). The trenches along the fault were excavated and showed about six paelo-earthquake events, which are 35250, 20250, 14750, 12150, 8550 and 4000 a. B.P., respectively, therefore, the recurrences of the events are much longer and characterized by asymmetry (XIANG et al, 1999). The reasons of too long peloearthquake recurrences are correlated with the reduction of tectonic activity compared to the main strike-slip fault zone of Haiyuan, besides the possibility of loss peloearthquake events in the field. Because the eastern Liupan Shan piedmont fault slip rate is low, the recurrence intervals of paleoearthquakes are relatively longer. This feature resembles the Xiaokou fault, which is the eastern segment of 
Haiyuan fault zone (Figure 2, $F_{2}$ ). The three peloearthquakes discovered along the Xiaokou fault segment, all occurred before 6000 a. B.P., and the average recurrence interval is $3000 \mathrm{a}$, longer than the peloearthquake recurrence interval along the middle and western segments of Haiyuan fault (ZHANG et al, 2003). The Haiyuan M8.5earthquake in 1920 A.D. is the latest rupture event of the Xiaokou fault segment.

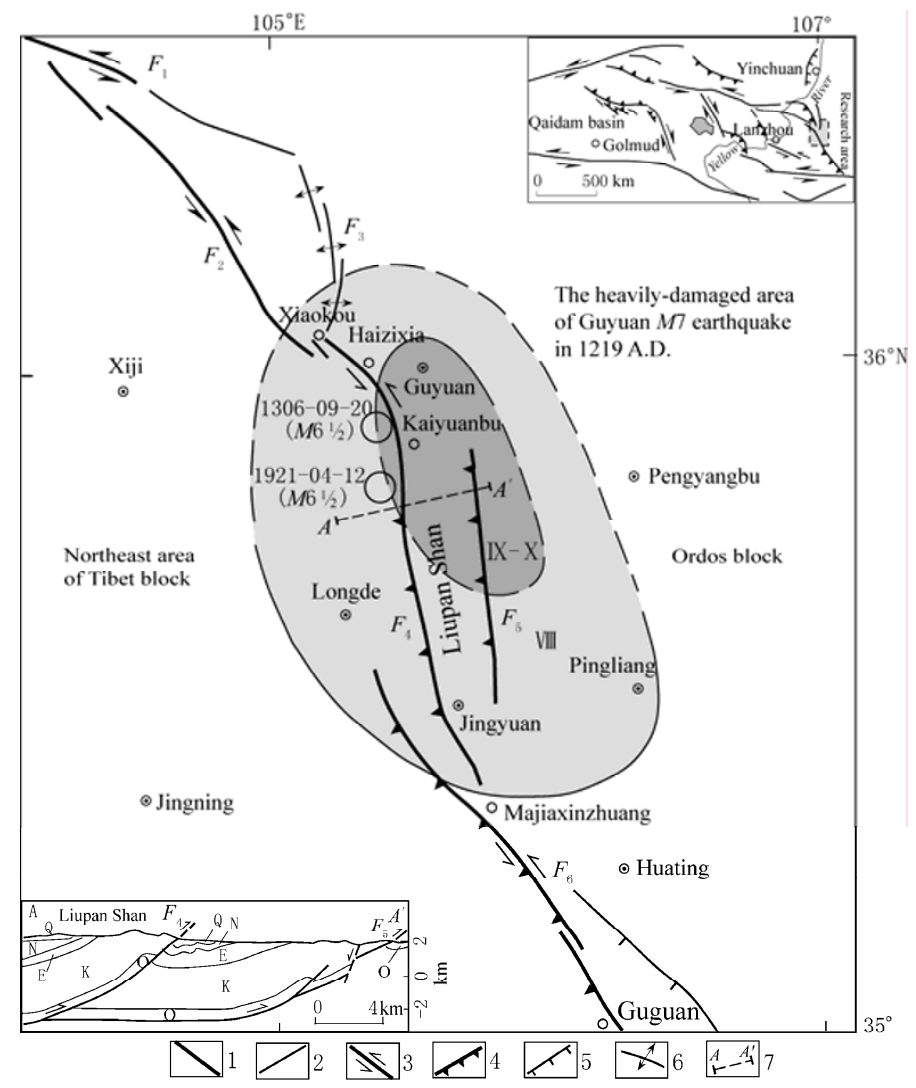

Figure 2 Distribution of active faults in Liupan Shan area

1. Ordovician; 2. Cretaceous; 3. Eocene; 4. Neocene; 5. Quaternary; 6. Late Quaternary active fault; 7. Early Quaternary fault; 8. Strike-slip fault; 9 . Thrust fault; 10. Normal fault; 11. Active folding; 12. Location of profile. $F_{1}$. Haiyuan main fault; $F_{2}$. Xiaokou fault; $F_{3}$. Madong Shan fold zone; $F_{4}$. Eastern Liupan Shan piedmont fault; $F_{5}$. Xiaoguan Shan fault; $F_{6}$. Guguan-Gongxian fault. The iconograph at the left corner modified from Zhang et al, 1991

The Xiaoguan Shan fault (Figure 2, $F_{5}$ ) is located at east of the eastern Liupan Shan piedmont fault. During Pliocene, Xiaoguan Shan fault and its north side the Madong Shan fold zone together constituted an important part of the Haiyuan thrust fault system. But since late Quaternary, the tectonic activity was transferred to the eastern Liupan Shan piedmont fault. The new activity of Xiaoguan Shan fault itself has to some extent reduced, therefore, the geomorphological and geological evidences of the new activity are not very clear (Zhang et al, 1991). According to the geological mapping results (Zhang et al, 1991), the eastern Liupan Shan piedmont fault and Xiaoguan Shan fault together constitute a low angle reverse nappe tectonic zone which was thrusted from southwest to northeast (Figure 2, $A-A^{\prime}$ ), both of them controlled the late Cenozoic tectonic deformation and present structural activity. The shape of the isoseismal line of Guyuan earthquake in 1219 A.D. reflects this kind of tectonic activity features. The major axis direction is 
about north-northwest direction, which is consistent with the direction of the eastern Liupan Shan piedmont fault and Xiaoguan Shan fault, but along the minor axis direction, the isoseismal line is asymmetry, wide in the west side and narrow in the east side, which means the earthquake damages attenuation faster eastward and slower westward, which is consistent with the features as thrusting from southwest to the northeast direction. That also reflects that the southwestern wall is the initiative wall, so the damages are serious and the influenced area is larger. Further more, the heavily-damaged area (the area of intensity VIII) is just located along the eastern Liupan Shan piedmont fault and Xiaoguan Shan fault, which further indicates activities of both these two faults caused the earthquake $M 7$ in 1219 A.D..

Because the eastern Liupan Shan piedmont fault $\left(F_{4}\right)$ had not only changed its extending direction compared to the Xiaokou fault $\left(F_{2}\right)$, east segment of Haiyuan fault, but also had a rupture segmentation boundary between them, the Madong Shan thrust-fold zone $\left(F_{3}\right)$, the thrust tectonic zone of Liupan Shan usually has the potential for independent rupture and causing earthquakes. The earthquake $M 7$ in 1219 A.D. is a typical exemplification. After this earthquake in 1219 A.D., about 87 years later, another strong earthquake occurred on September 20, 1306 A.D. (August Renyan, the tenth year of Dade of Emperor Cheng in Yuan Dynasty) in Kaicheng prefecture (Kaiyuan town) (Figure 2). The Kaicheng prefecture was suffered the devastated damages. According to the History of Yuan Dynasty • Annals of Emperor Wu (Vol.21) and the History of Yuan Dynasty • Civilian Records recorded "An earthquake occurred in Kaicheng prefecture, and then the royal palaces and official and citizen houses were nearly all collapsed, and more than 5000 people died including Yeliwan, the former queen of Emperor Qin, finally the government aided the victims by about 13 600 ingots of silver and grains more than 44100 Dan (Chinese unit of dry measure)". The History of Yuan Dynasty • Annals of Emperor Wu (Vol.22) recorded "At the day of Renyan, the second year of Zhida of Emperor Cheng in Yuan Dynasty, the government official expostulated the Emperor that "the officials of Shaanxi province said, Kaicheng prefecture occurred an earthquake in former period, the civilians were living much harder, we should remit their taxes for two years, and their taxes during this year", the Emperor agreed" (XIE et al, 1983; Lanzhou Institute of Seismology, State Seismological Bureau, 1989). The earthquake catalogs shows that this earthquake magnitude is about 61/2 (Department of Earthquake Disaster Prevention, State Seismological Bureau, 1995), and the epicenter is located at northern side of the 1219 A.D. epicenter area. It can be considered as a group of gathered earthquakes with the earthquake of 1219 A.D.

Because there had been two historical earthquake rupture events in 1219 A.D. and 1306 A.D. along the thrust fault zone of Liupan Shan, the eastern rupture of the Haiyuan earthquake M8.5 in 1920 A.D. was terminated at about Xiaokou (Zhang et al, 1991). The historical earthquake activities along the above two fault segments had caused the whole Haiyuan-Liupan Shan fault zone ruptured. At the same time, influenced by the Haiyuan earthquake M8.5 in 1920 A.D., another strong $M 61 / 2$ earthquake was generated near Guyuan city in Liupan Shan tectonic zone, with the epicenter at $106.2^{\circ} \mathrm{E}, 35.8^{\circ} \mathrm{N}$. The damages of this earthquake were reported as "landslides were more than 30 around the Liupan Shan. And in the vicinity area of Liupan Shan, the lands and houses were destroyed, and the uncountable people and domestic animals died" (Lanzhou Institute of Seismology, State Seismological Bureau, 1989). Comparatively, the damages and influenced area of the 1921 A.D. Guyuan M6 $1 / 2$ earthquake both are smaller than the earthquake in 1219 A.D., it proves from other view that the magnitude $M 6^{1 / 2} 2$ is a little small which was recorded by the present earthquake catalogs, and it should be about $M 7$. All these reflect that the thrust tectonic zone of Liupan Shan has the capacity of independent rupture and causing earthquake, and its latest tec- 
tonic activity during late Quaternary controls the earthquake activity in Liupan Shan region.

\section{Conclusions}

1) On the basis of the textual research on the historical earthquake data and the field surveys, we eliminate the ambigous recognition about the 1219 A.D. Guyuan earthquake, and definitely suggest that there is only one strong earthquake around Guyuan area, not two or three earthquakes. Comprehensive analysis indicates that the earthquake parameters from the present earthquake catalogs are not accurate and therefore amendments should be made. The time of the earthquake occurred should be at about 11 am, August 7 (at the time shi, June 18, the third year of Xingding), in 1219 A.D. The heavily-damaged area of this earthquake, the VIII intensity area, should be located at the area among Guyuan city, Pingliang city and Longde county city. Its epicenter area should be in the center of the three cities, but much more adjacent to Guyuan city. The magnitude of this earthquake is about 7 with an intensity of about $\geq \mathrm{IX}$ in the epicenter area. The epicentral location further was modified to coordinate of $35.9^{\circ} \mathrm{N}, 106.3^{\circ} \mathrm{E}$, with a precision degree of III.

2) The major axis direction of the heavily-damaged area should be in the north-northwest direction that is approximately consistent with the strike of the Liupan Shan low angle reverse nappe tectonic zone. As one branch of the Liupan Shan tectonic zone, the eastern Liupan Shan piedmont fault is a late Quaternary left-lateral thrust fault zone. The new activity of eastern Liupan Shan piedmont fault and the east Xiaoguan Shan fault segment together generated the $M 7$ Guyuan earthquake in 1219 A.D.

\section{References}

China State Bureau of Quality and Technical Supervision. 1999. China Earthquake Intensity Table (GB/T17742-1999) [M]. Beijing: China Standard Press: 1-3 (in Chinese).

Compiling Committee of Annals of Jingning County. 1993. Annals of Jingning County [M]. Lanzhou: Gansu People's Publishing House: 59, 86, 461 (in Chinese).

Compiling Committee of Annals of Longde County. 1998. Annals of Longde County [M]. Yinchuan: Ningxia People's Publishing House: 7, 564, 570-571, 654-655 (in Chinese).

Compiling Committee of Dictionary of Gansu Province. 2000. Dictionary of Gansu Province [M]. Lanzhou: Cultural Press of Gansu: 17-18 (in Chinese).

Department of Earthquake Disaster Prevention, State Seismological Bureau. 1995. Historical Strong Earthquakes Catalogue in China [M] Beijing: Seismological Press: 30 (in Chinese).

Earthquake Administration of Ningxia Hui Autonomous Region. 1982. Earthquakes Catalogue in Ningxia Region [M].Yinchuan: Ningxia People's Publishing House: 1, 140 (in Chinese).

Earthquake Administration of Ningxia Hui Autonomous Region. 1988. Collection of Earthquake Data of Ningxia Region [M]. Beijing: Seismological Press: 8-10 (in Chinese).

GU Gong-xu. 1983. Earthquakes Catalogue in China (1831 B.C. 1969 A.D.) [M]. Beijing: Science Press: 15 (in Chinese).

GUO Zeng-jian and QIN Bao-yan. 1973. Primary discussion on the models of earthquake focus [J]. Acta Geophysics Sinica, 16(1): 43-48 (in Chinese).

Institute of Geology, State Seismological Bureau and Ningxia Hui Autonomous Region Seismological Bureau. 1990. Haiyuan Active Fault Zone [M]. Beijing: Seismological Press: 121-136 (in Chinese).

Lanzhou Institute of Seismology, State Seismological Bureau. 1985. Catalogue of Strong Earthquakes in Shaanxi, Gansu, Qinghai Provinces and Ningxia Autonomous Region [M]. Xi'an: Shaanxi Scientific and Technological Press: 14 (in Chinese).

SUN Zhao-min and DENG Qi-dong. 1994. The basic features and interrelation between eastern Liupanshan piedmont fault and Longxian-Baoji fault [C]//Active Fault Research in China. Beijing: Seismological Press: 114-125 (in Chinese)

TAN Qi-xiang. 1982. Historical Geography Maps in China: Volume 6 [M]. Beijing: Sinomaps Press: 57-58 (in Chinese).

XIANG Hong-fa, GUO Shun-min, ZHANG Bing-liang, et al. 1998. Active features of the eastern Liupanshan piedmont reverse fault zone since late Quaternary [J]. Seismology and Geology, 20(4): 321-327 (in Chinese with English abstract).

XIANG Hong-fa, Ikeda Y, ZHANG Wan-xia, et al. 1999. Study on peloearthquakes of the eastern Liupanshan piedmont fault zone [J]. Earthquake Research in China, 33(8): 705-713 (in Chinese with English abstract).

XIE Yu-shou and CAI Mei-biao. 1983. Collection of Historical Earthquake Data in China: Volume I [M]. Beijing: Science Press: 155-158 (in Chinese).

Zhang Pei-zhen, Burchfie B C, Molnar P, et al. 1991. Amount and style of late Cenozoic deformation in the Liupanshan area Ningxia autonomous region, China [J]. Tectonics, 10(6): 1 111-1 129.

ZHANG Pei-zhen, MIN Wei, DENG Qi-dong, et al. 2003. Peloearthquake rupture behavior and recurrence of great earthquakes along Haiyuan fault [J]. Science in China (Series D), 33(8): 705-713 (in Chinese). 